\title{
Designing Out Crime at Bus Terminals in Nigeria: An Exploratory Analysis
}

\author{
Christopher A. Wojuade
}

Department of Transport Management, Ladoke Akintola University of Technology, Ogbomoso, Oyo State, Nigeria.

\author{
Adewumi I. Badiora \\ Department of Urban and Regional Planning, Wesley University, Ondo, Ondo State, Nigeria.
}

\begin{abstract}
Transit stops usually correlate with high human and crime activities. Having obtained information from transport facility managers and users, this study explores crime prevention and perception of safety at Nigerian Bus stations. This study compares and contrasts the perceptions of users and transport service managers in relation to selected bus stations (Ring road and Uselu) in Benin City as a case study. From the perception of the managers, it was believed that both bus stations observed design principles for crime prevention but that of ring road was planned more effectively than Uselu. This suggests that ring road bus stations should be perceived to be safer. Surprisingly, this was not as the users felt the other bus station was slightly safer. An assessment of landuses within $150 \mathrm{~m}$ radius to each bus station showed that ring road station is someway in close proximity to several landuses likely to generate, attract, and facilitate crime. Hence, we speculate that the activity generated from these landuses may have negatively influenced perceived feeling of safety at this terminal. These findings thus, suggest that the surrounding environment acts to mediate perception of safety and effectiveness of crime prevention strategies of a site. The study therefore, concludes that safety and security planning of a place could be applied better by considering not only the security strategies but also the immediate surrounding environment.
\end{abstract}

\section{Indexing terms/Keywords}

Bus station; Surrounding environment; Convergence of crime; Feeling of safety

\section{Academic Discipline And Sub-Disciplines}

Transportation

\section{SUBJECT CLASSIFICATION}

\author{
JEL Classification System
}

\section{TYPE (METHOD/APPROACH)}

Survey/Interview

\section{INTRODUCTION}

Crime has become major social problems across towns and cities all over the World. Particularly, there has been a noticeable upsurge in the incidences of crime in most less developed countries of Africa and Asia (World Bank, 2015). It is a common truism that in towns and cities across most developing nations, the risk to lives and properties are becoming common features on transport routes and bus stations (Ajayi and Ajayi 2014). Home-based and non-home-based trips can result in being mugged, assaulted, robbed, and raped among others. Particularly, for those who use public transit infrastructure, miscreants regularly burgle their paths at specific points on transit, usually in the so-called transits stops. In a nutshell, one of the public transport facilities in Nigeria, which have become a veritable platform for criminal elements to perpetuate their nefarious activities, is the public bus stops/bus stations (Ajayi and Ajayi 2013) and their immediate surrounding environment.

Till lately, crime in Nigerian transport environment covers some notable offences like pick-pocketing, stealing, robbery, assaults, grievous bodily harm and wounding, breach of public peace, drug dealings and hooliganism. Users of transport facilities have become victim at different time of the day and week while walking to, from or between bus stations, waiting at bus stations and travelling on bus. However, crime at Nigerian transport environment has moved from the normal level of crime to the act of terrorism and kidnapping. On April 4, 2014, an early morning explosion that frayed through the Nyanya transit park in the outskirts of the Nigerian capital, Abuja, killed at least 71 people and injured 124 as hundreds of commuters travelled to work. The explosion destroyed 16 high-capacity buses and 24 minibuses, many of which were loaded with passengers. In August 22, 2015, a suicide bomber killed 5 and wounded 41 people in an attack at the crowded entrance to a bus station in Damaturu; capital city of Yobe State in northeast Nigeria. On June 6, 2017, 3 passengers were abducted form Lagos-Benin commercial bus at Benin City by-pass near Oluku station in Benin City. Furthermore, on 7th of August 2017, gunmen abducted 15 passengers in Rivers State when they hijacked a Lagos-bound commercial bus. The incident occurred around Elibrada community bus terminal along the east-west road in Emohua Local Council Area. These and many more are cases of heinous crime that may affect the quality and perception of public transportation system in Nigeria.

Researches have demonstrated consistently that crime and fear of crime can affect the quality of public transport (Dragu, Roman, and Roman 2013) and levels of public transport patronage (Cozens et al. 2004; Delbosc and Currie 2012). It has 
been proven that patronage levels could be more than $10 \%$ higher if commuters felt more secure when traveling and waiting at transits stop bus stations (Crime Concern 2004). While, crime on public transport is relatively rare (Batley et al. 2014), studies around the world continue to document the morphology of high crime places to include transport bus stations. Page et al (2001); Page et al (2001a); Smith and Clarke (2000); Thompson et al. (2012); Batley et al. (2012) all noted that transit stop environment encompasses factors whose presence is necessary to warrant crime. First, lack of suspicion by others aids in the offender diverting attention from him. Second, easy entrance and exit keep the risk of getting caught relatively low and finally, the targets lack of knowledge about the area and others in the area leaves him or her susceptible to victimization.

Perceptions of safety are influenced by many factors. These include the built environment and the design of transits stop bus stations (Cozens, 2002; Cozens et al. 2003a, 2003b, 2004; Smith 2008; Atlas, Sorensen and Hayes, 2008; Vilalta 2011; Delbosc and Currie 2012). Thus, it follows that good environmental planning may decrease crime. Crime prevention through Environmental Design (also know as designing out crime) is now a relatively common approach used to reduce crime and the fear of crime in and around transit bus stations (Cozens 2014; Batley et al. 2012). Like many other countries, Crime prevention through Environmental Design (CPTED) has been increasingly used to reduce crime in and around transits bus stations in Nigeria. CPTED is considered to be best practice and represents a large investment of public and/or private funds in the country. Despite this, little is known about CPTED investment in relation to bus stations in Nigeria. It is also important to note that most studies on CPTED in relation to transport safety only narrate the experience from Western countries (See Cozens 2002, Cozens et al. 2003a, 2003b, 2004; Thompson et al. 2012).

While these studies have enhanced understanding of CPTED in relation to transit stop safety, there still exist many more unanswered questions. For instance, very little is known about the influence of other features of designing out crime such as the wider environment. Also, findings in the Nigeria context are missing from the literature. Road transport in the country has moved from just conveying people from one place to another to highly competitive, customer service packed and value added services. This study therefore, explores the relatively under-researched elements; security of transport bus station using environmental design principles in relation to two purposively selected bus stations in Benin City, Nigeria. This research compares and contrasts the commuters' and transport managers' perceptions of crime and crime prevention at these two bus stations.

\section{BUS STATION AND THE CONVERGENCE OF CRIME}

In the morphology of high crime places, there are two fundamental and relevant principles in relation to transit bus stations. They are routine activity and social disorganization. Cohen and Felson (1979) developed the Routine Activity (RA) theory to explain why crimes occur. Routine activity suggests that each successful crime has at least one motivated offender and at least one personal or property target and requires the absence of an effective guardian capable of preventing its occurrence (Breetzke and Cohn, 2012). The idea as originally conceptualized addresses how the movement of motivated offenders throughout a city shapes spatial patterns of crime when this movement overlaps with places where suitable targets or victims congregate and where there is no person or entity to properly guard the target. Targets of crime can be a person or an object, whose position in space or time puts it more at risk of criminal attacks. Interestingly, capable guardians are normally not police officers but rather anybody or device whose presence or proximity would either prevent or discourage a crime from happening. Although police do fall into the category of guardian, normal citizens or devices more frequently play the role. Therefore, passers-by, visibility, lighting, security camera among others would tend to serve as guardian by being present.

Routine activity theory can be used to explain why certain environments (such as bus stations) give rise to criminal behavior. A bus station brings together large amounts of people simultaneously. This group of people can be composed in a couple of different ways. First, the group could be composed of all suitable targets. These targets are transported to transit stop where offenders can victimize them. Secondly, the group of travelers can be composed of both suitable targets and potential offenders. This development is most likely the veracity at peak times for transit use, when the traveler population is at its highest. Although, it is absolutely true that capable guardians are present within these groups identified above, we would argue however that at least one of potential victim and offender is always present, but a guardian need not be. Capable guardians do exist, nonetheless. However, this group of travelers will disperse eventually. The commuters do not all share the same destination. Due to this fact, the capable guardians amongst the commuters get filtered out. As the group separates the probability that capable guardians would hinder crime shrinks, simply because of their decreased presence.

Social disorganization on the other hand focuses on place of crime occurrence and tries to explain why some places experience high levels of crime while others do not. Shaw and McKay (1942) described the characteristics of a socially disorganized place as including: high human activities, high population density, population mobility or transient people (people constantly moving in and out of the place), poverty, and the physical decay/poor maintenance of the buildings in the place. As an area begins to decay, it is thought that crime rates will rise due to the lack of social control. The thrust of social disorganization therefore is that there are ecological factors that are responsible for high rates of crime in different places, and these factors are linked to constantly elevated levels of deteriorating infrastructures.

The theory has been used to explain transport crime in many ways. First, transit stops usually correlate with high human activity (Ajayi and Ajayi, 2013). As well, these areas also correlate with high crime activity (Ajayi and Ajayi, 2014). Literature suggests that the "presence of a transit station often affects the relative danger in the immediate area" (Block and Block 2000). This suggests that transit stations and stops serve as behavior settings conducive to criminal activity. Brantingham and Brantingham (1993) describe a behavior setting as a location where desired behavior may be carried out. For example, an empty household may be a behavior setting for a person seeking to commit burglary. A department 
store may be a behavior setting for a teenager who desires to steal a new outfit. Similarly, the area around transit stops may serve as a behavior setting for individuals looking to commit robbery, due to the routine activities of the transit riders, others in the area, and the environment itself. Simply put, areas with high rates of public transportation usage find more transient people in public places, thereby increasing the opportunity for a crime to occur (Cao and Maume, 1993).

It is evident from the above that that the characteristics of transit stops and their surrounding environment facilitate the occurrence of predatory crime. Thus, it follows that good environmental design may decrease crime and fear of crime. CPTED is now a relatively common approach used to reduce crime and the fear of crime in and around transit stations. The next section focuses on this CPTED concept.

\subsection{Concepts of designing out crime}

The use of environmental design strategies to ensure security of life and properties can be traced to early human settlements. These include the establishment of iron-age forts and castles, which used landscaping, walls, moats, and drawbridges to control access (Schneider and Kitchen 2002; 2007). Preliminary researches into environmental design practices for crime prevention can be traced to Jacobs (1961) and Newman (1972, 1973). In 1961, Jacobs developed the idea of altering the environment to influence the crime rate. Latter, Newman (1972) developed a number of guidelines to make areas safer and more 'defensible' against crime. The resulting defensible space theory identifies design principles that are tangible and can be implemented in actual neighborhoods and for individual houses. This led to the development of crime prevention through environmental design (CPTED), which utilizes carefully planned designs in order to prevent crime (Peeters and Beken, 2017). These design principles that deter crime can be implemented in transport bus stations and streets and also in individual houses.

CPTED focuses on seven key concepts (Cozen 2014). These are territoriality, surveillance, image management and activity support. Others are access control, target hardening, and wider environment (See Figure 1). However, the main CPTED concepts are territoriality or defensible space, access control, surveillance, and image or maintenance (Cozen 2008; Armitage, 2016; Peeters and Beken 2017). These CPTED ideologies play a significant role in shaping perceptions of safety not only in residential areas but also at stop bus stations. Territoriality refers to designing spaces in a way that provides a sense of ownership and proprietary concern by residents/users so that they potentially are more likely to act as guardians (Cozens and Love, 2015). Access control is related to the ease of access to buildings or areas (Cozens, 2008; Ekblom, 2011).Access control is related to territoriality in that it helps define private and public space and controls who enters a specific site and can include card entry systems, bollards, fencing, and walls (Cozens, Saville, and Hillier 2005; Atlas, Sorensen and Hayes, 2008). Surveillance is about how design can enhance visibility.

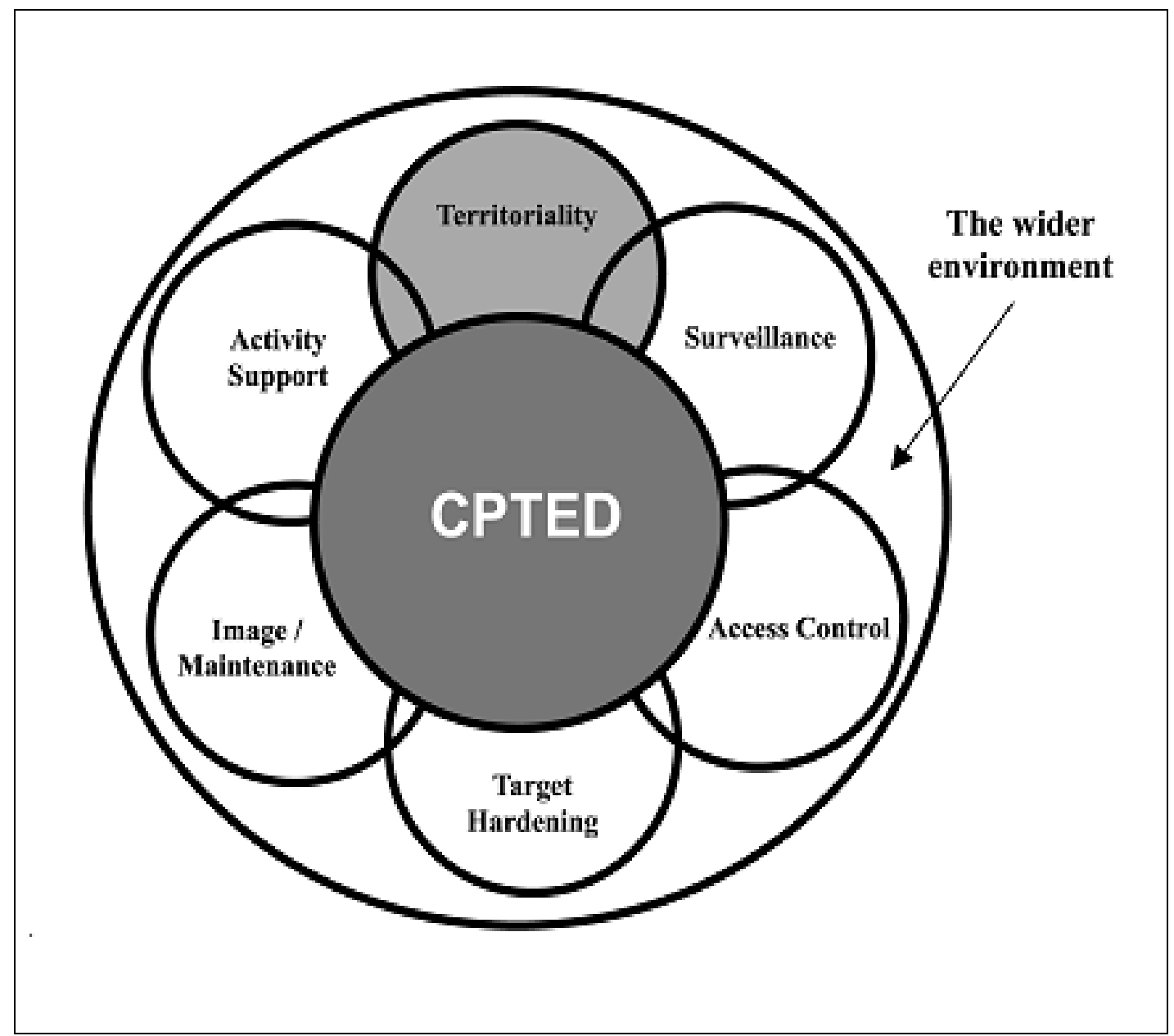

Figure 1: Components of CPTED; Source: Cozens 2014 
Surveillance is the ability to observe what happens in the area or around the house. It is linked to how visible the property is to neighbors (Armitage \& Joyce, 2017; Cozens, 2008; Ekblom, 2011). It can be promoted or hindered by environmental design and can influence crime and the perceptions of safety of those using such spaces (Cozens et al. 2004; Moore 2010). The use of good lighting, closed circuit television (CCTV) and security guards is means of promoting the opportunities for surveillance (Ziegler 2007; Cozens 2014). Image or maintenance is about whether the area looks cared for. An area with more disrepair is related to a higher risk of crime (Weisburd, Groff, \& Yang, 2012). A clean and well-kept environment provides a sense of orderliness and control, which can nurture perceptions of safety as well as deter criminals (Wilson and Kelling 1982; Cozens and Love 2015). Examples include the rapid removal of graffiti and the prompt repair of vandalism (Smith and Clarke 2000; Vilalta 2011).

At this juncture, it is important to note that one of the CPTED elements that are rarely considered is wider environment (Cozens 2014). This is the influence that nearby landuses may have on the security of a particular site (Newman 1973; Cozens 2014). This particularly relates to land uses that have the tendency to generate crime, such as hotels, retail shops, seedy inns, vacant lots/buildings, and cash converters/pawn shops (Newton 2004). This also has been observed in relation to public transport with regard to bus stops (Loukaitou-Sideris et al. 2001; Newton 2008). Therefore, it is likely that in addition to the CPTED concepts discussed above, the wider environment plays a significant role in shaping perceptions of safety at stop bus stations (Cozens, 2014). This has been corroborated in the field of environmental criminology.

According to Felson and Boba (2010), different types of settings generate large amounts of crime. The riskiest settings according to them include public routes (especially footpaths, parking facilities, and unsupervised transit areas), recreational settings (especially bars and parks), public transport (especially stations and their vicinities), retail stores (especially for shoplifting), educational settings (especially at their edges), offices (especially when entered for theft), human support services (especially hospitals with 24-hour activities), and industrial locations (especially warehouses with "attractive" goods). This relates to the routine activities of the area and the potential location of crime generators, crime attractors (Brantingham and Brantingham 2008), crime detractors (Kinney et al. 2008), crime facilitators (Clarke and Eck 2005), and crime precipitators (Wortley 2008).

According to Brantingham and Brantingham (2008), crime generators are activity nodes that pull masses of people toward them, who don't necessarily have any predetermined motivations to offend, but they act on criminal opportunities if they become evident. Crime attractors are activity nodes with well-known opportunities for crime that can entice motivated offenders. Crime detractors are locations that have few attractions and can push people away. This can then encourage use by potential offenders (Kinney et al. 2008). Crime facilitators according to Clarke and Eck (2005) are things that foster the capability of offenders in circumventing existing crime prevention measures. They can be physical (e.g. firearms), social (e.g. gangs and organized criminal networks), or chemical (e.g. alcohol/drugs). Crime precipitators are things in the immediate environment that actively encourage individuals to commit crimes who would not normally consider offending (Wortley, 2008). Although such locations resonate with Newman's (1973) Defensible Space concept of geographical juxtaposition, it has been argued that the surrounding environment has not been subject to much research in the field of CPTED (Cozens 2014). This is particularly the case in relation to the research on bus stop stations; hence this study.

\section{MATERIALS AND METHODS}

Benin City is the capital of Edo State in Nigeria. The City has one of the largest and organized transport services in Nigeria. This is because of its road junction linking Northern, Eastern and Western parts of the country. The city has a regional setting endowed with easy access from all parts of the country. The city road network is managed through the Department of Works and Transport; a government agency responsible for providing and managing the train, bus, and ferry networks. Private individuals and organizations are also allowed to partner and operate transport services. Private transport managers also take responsibility for the efficient and safe running of vehicles carrying passengers and/or goods. There are various reliable transportation services in Benin City that convey passengers and luggage across the length and breadth of Nigeria. Some of them also transport passengers to countries outside Nigeria, especially West African countries like Ghana, Togo, Cote D'Ivoire, and Benin Republic among others. Bus stations are numerous in Benin City and located in areas such as ring road, Akpakpava, Uselu, Benin-Lagos Expressway, Ugbowo, Oredo, Dawson Road and Sapele Road among others. Passengers make choices on which transport service/bus station to use base on a lot of factors; chief among are safety, security and welfare. Overall, it is estimated that these transport facilities provide services for approximately 13 million passengers per year (Ministry of Transport 2015).

This study was conducted during the second quarter of 2015 in Ring road and Uselu bus stations in Benin City, Nigeria. The former is located at the traditional city center while the latter is situated at the suburb. This study gathered three different types of data. First, twelve (12) transport managers were interviewed about crime and the security strategies used (or not) at each bus station. Snowball sampling techniques was used to select the managers. That is, having located the first respondents, next respondent was introduced by the previous respondent. Transport managers are responsible for safety, security and allocation of transport staff in the bus stations. They also plan, organize, direct, manage, evaluate, and are responsible for the operations of transportation departments, services and facilities.

Second, one hundred and twenty (120) survey questionnaires were administered (60 at each bus station) on the users. These are passengers who make their trip from these bus stations. This figure is based on the convenience of the authors and not randomized sample. This convenience sampling allows us to obtain basic data regarding perception of crime and safety without the technical hitches of using random sampling techniques. Questionnaire was administered on those commuters who were willing to participate and supply the required information. The questionnaire were directed at eliciting data on: (a) perceptions of safety while at the bus stations and when entering or exiting the bus stations; (b) respondents' perceptions of the presence or absence of security qualities, including visibility (lighting) at the bus stations, (particularly in 
the dark), surveillance from passers-by and surrounding landuses, and security guards and; (c) respondents' perceptions of the general image of the bus stations and whether this would deter them from using the bus stations. To ensure an adequate understanding of the perception of safety in the study area, some users were further engaged in discussion on their perception (particularly those who had experienced and/or witnessed one crime or the other in study area). Information elicited was analyzed through content analysis and ethnographic summaries, using narrative techniques of reporting.

The third involved conducting a basic appraisal of the landuses and activities surrounding the two bus stations. This was to provide some insights in the local context and the influence of wider environment on perceived safety, and the security qualities at the two bus stations. The landuses appraisal was done within $150 \mathrm{~m}$ radius of the bus stations. The user's questionnaires adopted a simple quantitative method. However, some users were further interviews through qualitative method. The interview with facilities managers was both quantitative and qualitative. This facilitates a more all-inclusive meaning and comparison of the results from both the users and service providers. These also could be contrasted with the landuse and activities appraisal to further explore the potential influence of the wider environment in which the bus stations are located. Findings are as discussed in different sub-sections as follows. Unless where otherwise stated, tables and figures in the next sections are the outcomes of the author's field survey in the second quarter of 2015

\section{RESULTS AND DISCUSSION}

Respondents in the final sample were between 16 and 68 years of age $(M=45.54, S D=18.07), 53 \%$ were male, $61 \%$ had lived in the city for more than 15 years, and $94 \%$ identified their main ethnic or national group to be Nigerian. Seventy per cent $(70 \%)$ of respondents were married, $43 \%$ had attained a University degree, and $87 \%$ of respondents earned more than \#18,000 (national minimum wage) per month. It is therefore evident that the quota sampling used in this study was found to be broadly representative of the overall population living in the city (e.g., gender, age, income and education level, and number of people living in household).

\subsection{Transport managers' perception of the bus stations}

In order to investigate service managers' opinions on crime and safety at the two bus stations, twelve (12) transport service providers/managers were interviewed. When asked if they perceived security were considered in the design of Ring road and Uselu bus stations, all (100\%) respondents confirmed that both bus stations has been designed with consideration of one or more CPTED principle. Nevertheless, they were of the opinion that CPTED were well detailed at Ring road bus station than at Uselu bus station. Hence, the transport service providers/managers believed that Ring road bus station was designed more effectively than Uselu bus station. Respondents (75\%) believed that Ring road bus station was well designed and that lighting was particularly considered to be of a high standard at Ring road bus station. Nonetheless, it was also noted that despite the use of CPTED at Ring-road bus station, findings showed that $38 \%$ of the transport service providers/managers interviewed believed that surrounding landuses and happenings did not produce a lot of activity to provide inert surveillance of the bus station. Although $25 \%$ of the transport service providers/managers believed the design of Ring Road bus station was effective in increasing perceptions of safety and security, they make known that it was necessary to upgrade the bus station and provide more lighting, surveillances and security persons to monitor entry and exit points in order to increase safety.

Having explored the transport service providers/managers' opinions on security and crime prevention in the two bus stations, this study turns to the commuters. Findings are presented in the next section.

\subsection{Commuters' perception of the bus stations}

This section discusses users' reactions to questions of this study (See Methodology). Respondents could respond to these questions using one of five-item Likert scale of "strongly disagree (SD)," "disagree (D)," "neither agree nor disagree (NAD)," "agree (A)" and "strongly agree (SA)." The number of responses out of 60 commuters interviewed was recorded per description and expressed as a percentage score. Findings are summarized in Tables 1.

From the summary presented in Table 1, overall finding indicates that respondents felt a little bit safer at Uselu bus station $(83 \%)$ than they did at Ring road bus station (80\%). For Ring road bus station, findings show that $62 \%$ of the respondents agreed that they feel safe at this bus station. At Uselu bus station, $65 \%$ indicated that they generally felt safe at the bus station. For Ring road, $72 \%$ of the respondents agreed they felt safe entering and exiting the bus station in the dark, while $73 \%$ felt the same at Uselu bus station. At Ring road, $82 \%$ of the respondents agreed that the design of the bus station was visible and made them feel safe, compared to a slightly higher $90 \%$ of respondents at Uselu bus station. At Ring road, $58 \%$ of the respondents agreed that passers-by and neighboring landuses/activities could easily see into the bus station. At Uselu, $73 \%$ of the respondents agreed with the statement. When asked about the presence of lighting, $53 \%$ of respondents at Ring road and $60 \%$ at Uselu agreed that such surveillance was available, sufficient and functional. Findings showed that $77 \%$ and $87 \%$ of the respondents respectively, agreed that there were enough exits and security guards at Ring road and Uselu bus station to ensure their safety. In the overall, findings as summarized in Table 1 indicates that the respondents perceived Uselu (78\%) to exhibit a little bit higher levels of CPTED qualities than Ring road $(68 \%)$. 
Table 1: Users' perceptions of safety, Design qualities and image of bus stations

\begin{tabular}{|c|c|c|c|c|c|}
\hline \multirow[t]{2}{*}{ Variable } & \multirow[t]{2}{*}{ Description } & \multicolumn{2}{|c|}{$\begin{array}{c}\text { Ring } \\
\text { Terminal }\end{array}$} & \multicolumn{2}{|c|}{$\begin{array}{l}\text { Uselu } \\
\text { Terminal }\end{array}$} \\
\hline & & No & $\%$ & No & $\%$ \\
\hline \multirow[t]{3}{*}{ Personal Safety } & I feel safe at this bus station. & 37 & 62 & 39 & 65 \\
\hline & I feel safe entering and exiting the bus station in the dark. & 43 & 72 & 44 & 73 \\
\hline & It is visible and I feel secured. & 49 & 82 & 54 & 90 \\
\hline \multirow[t]{3}{*}{ Design Qualities } & $\begin{array}{l}\text { Passers-by and neighbours can easily observe what is } \\
\text { going on. }\end{array}$ & 35 & 58 & 44 & 73 \\
\hline & There is sufficient surveillance from lighting & 32 & 53 & 37 & 62 \\
\hline & $\begin{array}{l}\text { There are sufficient exits and security guards to ensure my } \\
\text { safety and security. }\end{array}$ & 46 & 77 & 52 & 87 \\
\hline \multirow[t]{2}{*}{ Terminals Image } & This bus station has a good image. & 20 & 33 & 30 & 50 \\
\hline & This image has an effect on my decision to use it. & 25 & 42 & 23 & 38 \\
\hline
\end{tabular}

When asked about the image of the bus station, answers revealed that $33 \%$ of respondents at Ring road bus station agreed that the bus station has a good image while $67 \%$ disagreed (See Table 1). At Uselu, findings showed that $50 \%$ of respondents agreed the bus station has a good image meliu even though; the same proportion agreed that the bus station has a bad image. Engaging the respondents in further discussion, it was discovered that respondents felt this way because they (some) have heard from others about breach of public peace, criminal and antisocial behavior that had occurred at and around the bus station. Some had witnessed crime victimization themselves, and many believed that the whole area, particularly the transitional area of Ring road, had a bad image. There were also concerns over the types of people at the bus station, including miscreants, drunkards, gamblers, hooligans, and suspect people hanging around.

In one of the discussion sessions, a commuter stated thus:

"Public fight, stealing and pick-pocketing are common crime types in this area. Hardly will a day pass without a case of property being stolen or misplaced. In fact, a friend's wallet containing a sum of twenty five thousand $(25,000)$ Naira and other valuable documents was carted away here in a broad daylight. Efforts to find the wallet did not succeed. Besides, I am an eye witness of a serious and deadly pubic fight among 'garage boys' in this place" (Civil servant/43 years/Benin City).

Another user said:

"How would person feel very safe in this kind of area? You must be extra 'sharp' here. Although the park itself is fairly good, my concern as a passenger is the types of people I see around this bus station. Some of the officials and their boys don't present themselves well. You rarely see dependable people. All you see around are miscreants, drunkards, gamblers, hooligans, and suspect people hanging around with cigarettes, liquor and 'ogogoro' sellers (Undergraduate/20 years/Benin City).

Furthermore, respondents were asked if the image affected their decision to use the bus station. At both Ring road and Uselu, findings showed that $42 \%$ and $38 \%$ respectively indicated that the poor image affected their use of the bus station. The majority of the respondents who agreed that Uselu bus station have a good standing stated that they had never seen or heard about any disorder or criminal behavior. Some stated that the bus station seemed safe and that there were always security guards around. This made them to feel safer.

In one of the interaction sessions, a user of Uselu terminal stated thus:

"This is the stop I always use whenever I am going on a journey because I think it is better than other stop stations in this city. The environment of the park is not always overcrowded. There is no hooliganism; I had not personally witnessed fights, assaults or victimization and drunks at and around the bus station before" (Business man/54 years/Benin City).

Another passenger said:

"The structure here is fair. However, I cannot say this place is totally secured. Because of my onetime experience, I could say occasionally, fights and assaults occur here but not as obtained in some parks in town. Although there are still a lot of improvements to make on security and safety services, mere 
seen security attendants, police services and patrol vehicles around make me feel that I am very much secured here. This park is also well lit in the night except there is general power outage (Students/Female/20 years/Benin City).

As shown in Table 1, overall, users surveyed felt that security qualities at Uselu bus station were a little bit more effective in making them feel safer than at Ring road bus station. They also felt that Uselu exhibited higher levels of security qualities and has a better image/maintenance than Ring road bus station. This is in contrast to what would be expected from opinion of service providers/managers interviewed; since they believed that Ring road bus station was designed more effectively than Uselu bus station. At Uselu bus station, findings show that $65 \%$ of respondents agreed that they felt safe (See Table 1). This was a little bit more than the proportion of respondents at Ring road, in which $62 \%$ agreed. In summary, respondents felt safer at Uselu bus station than at Ring road.

Having explored transport service mangers/providers and users' opinion on security and crime prevention in the two bus stations, this study investigates further by appraising landuses and activities around the bus stations to provide an indication of the immediate context of each bus station and to probe the issue of wider environment of the CPTED concepts.

\subsection{Landuse appraisal of bus stations' surrounding environment}

Benin City built environment is characterized by intensive landuse and human activities. It is believed that building or landuse features of an area seem to influence the concentration of crimes. Researches in crime pattern and safety have long taken certain landuse characteristic into consideration when accounting for urban crime patterns (See Ackerman \& Murray, 2004; Cahill \& Mulligan, 2007; \& Lockwood, 2007).

Hence, an assessment of these landuses and human activities around each bus station was therefore conducted. All landuses/activities were recorded within a $150 \mathrm{~m}$ radius of each bus station. Landuses were divided into various groups, including residential, commercial \& services and educational \& health institutions. Others are recreational, agricultural and industrial landuses.

Residential as used in this analysis included all housing structure. The residential category includes single-family residences and multiple-unit dwellings. Areas and buildings that are predominantly used for the sale of products and services are classified as commercial and services. This comprises hotels, motels and related facilities associated with leisure time activities containing over-night accommodations, dining facilities, services and recreational activities such as tennis courts, pools, and well-kept lawns and gardens (These features are included since they are private and not accessible to non-paying people). Other institutions such as churches, convents, special research facilities, medical research facilities not open to the public, and social clubs associated with established organizations were also audited as commercial landuses.

Educational institutions included all levels of public and private schools, colleges, higher institutions, Universities and training centers. Not included were recreational facilities opened to the public such as football fields, tennis courts, and swimming pools. These facilities are included in recreation. Any educational activity associated with religious institutions involving parish schools, seminaries and orphanages were audited under this category. Any health institutions or facilities providing direct health care to the public such as hospitals, mental health institutions, sanitariums, special care centers, major clinics and nursing homes are included in this category. Audited under recreational category were those areas which have been specifically developed for recreational activities and can be accessed by the general public. It also included any recreational facilities in other landuses category but is accessible to the public. However, any facilities that are part of a resort or leisure complexes and open only to patrons of the hotel or motel were not audited under this category, but under commercial and services category.

Table 2: Landuses surrounding each bus station

\begin{tabular}{lcc}
\hline Land Uses within 150m Radius & $\begin{array}{c}\text { Ring road Bus station } \\
\text { \% of Total Landuse Area }\end{array}$ & $\begin{array}{c}\text { Uselu Bus station } \\
\text { \% of Total Landuse Area }\end{array}$ \\
\hline Residential landuse & 27 & 38 \\
Commercial \& Services & 32 & 13 \\
Education \& Health Institutions & 10 & 14 \\
Recreational landuse & 25 & 20 \\
Agriculture land & 5 & 12 \\
Industrial land & 1 & 3 \\
\hline
\end{tabular}

\section{Note:}

a. Included with each of the above landuses are main building, secondary structures and supporting areas, associated lands, landscape, parking lots, access roads, communication and utilities as well as other appurtenances (There are few cases when some of these are specifically excluded. Such instances are noted in the main discussion). 
b. Where there was mixed landuses and the land or built-up areas cannot be separated into individual landuse categories at the assessment scale employed, such land or building was audited for dominant landuse (category with $\geq$ two-third landuse.).

\begin{abstract}
Agricultural land in this study is all lands use primarily for the production of food and fiber and some of the structures associated with it. The agricultural land audited were cropland and pastureland; orchards; vineyards; nurseries and horticultural areas and confined feeding operations. Industrial land audit encompassed light and heavy industries where manufacturing, assembly or processing of products takes place. It included industries dealing with design, assembly, finishing, packaging, and storing of products or materials. It also included facilities for administration, research, assembly, storage, warehousing, and shipping such as electronics firms, trucking companies, small textile mills, and auto assembly plants. Industrial land further included industries involve in the processing of raw materials such as iron ore, timber, petroleum or coal, or the fabrication and assemblage of parts that are bulky and heavy. Examples of such are steel, pulp, and lumber mills, oil refineries and tank farms, chemical plants, and grain mills. Presented in Table 2 is the estimated proportion of space each type of landuse represents at $150 \mathrm{~m}$ radius of both bus stations.
\end{abstract}

From this summary, it was revealed that $27 \%$ of the landuses within $150 \mathrm{~m}$ radius of Ring road bus station were residential. On the other hand, residential landuse accounted for $38 \%$ of landuse activities with $150 \mathrm{~m}$ radius of Uselu Bus station. Reverse was the case for commercial and retail activities as these activities accounted for $32 \%$ and $13 \%$ of landuses at Ring road and Uselu bus stations respectively. While educational and health institution accounted for only $10 \%$ of landuses around Ring road terminal, educational land use accounted for $14 \%$ of activities around Uselu bus terminal. The proportions of recreational landuse around Ring road and Uselu bus stations were $25 \%$ and $20 \%$ respectively. Agricultural areas are easily distinguished from the other categories and represent a relatively small landuse in the study area. Findings showed that agricultural land was more at $150 \mathrm{~m}$ radius of Uselu bus station environment (12\%) than ring road bus station (5\%). Industrial activities were lowest around the two stations. While this landuse accounted for only $1 \%$ of landuses within $150 \mathrm{~m}$ radius of Ring road station, it was $3 \%$ within the same distance to Uselu bus station.

It is obvious from the above that Ring road bus station is located in an environment dominated by commercial and services, including a variety of restaurants, hotels, motels, several shopping centers, and sales of liquor, retail shops, gambling establishment and money changers, among others. In any case, they appear to affect perceptions of crime and the perceived effectiveness of security strategies in and around the bus station. It is possible that the activity generated from these landuses may have negatively influenced perceived feeling of safety at Ring road bus station. Evidence from environmental criminology suggests such activities may act as crime attractors or crime generators. This result largely echoes theories and empirical findings of the ecological criminology in western countries which argue that those areas adjacent to the transition zone and business district have more crimes than other areas (See Cahill \& Mulligan, 2007; Lookwood 2007; Andreson, 2006; Ackerman \& Murray, 2004; Shaw \& McKay, 1942).

Usually, commercial areas in Nigerian cities are places where stores, restaurants, entertainment facilities, companies among others are concentrated, with large numbers of people who are actually not living there but working or shopping there as their routine activities. The concentration and mobility of population tend to increase the number of profitable targets and likely offenders in those places, at the same time lessen the chance to be caught. It is reasonable to expect that places where a lot of people gather for routine activities, such as working and shopping, are more likely to have more criminal activities. In the commercial areas, people are usually strangers to each other, thus lowering the social control that is more effective among the acquaintances. Especially at night, people walking in or near the commercial areas are extremely prone to robberies, due to the lack of guardians after most of the commercial businesses are closed. These observations are basically in line with the routine activities which emphasizes the convergence of motivated offenders, suitable targets, and the absence of capable guardians in interpreting local crime events.

In contrast, Uselu bus station is located in the suburb and surrounded by a predominantly residential, educational, agriculture and industrial environment. The land uses surrounding Uselu bus station does not appear to represent crime attractors or crime generators. For instance, the functionality of industrial areas tends to be more monotonous with lower population density and less degree of mixture with other activities, particularly commercial activities. This could help bring down the number of potential offenders and targets, and subsequently the opportunities for crimes. Besides, many of housing units in the residential areas have existed for decades, as a result of which people living there are likely to know each other and tend to develop a solid social coherence, thus having the effect of lessening the risk of crimes. It seems that feeling of safety is increased in Uselu areas compared with the Ring road area, owing to the routine activities and perhaps enhanced social organization and social control in these areas.

\title{
5. CONCLUSION AND IMPLICATIONS FOR FUTURE STUDY
}

This study explores perceptions of crime and crime prevention at Nigerian bus stations using Benin City as a case study. This study compares and contrasts the perceptions of users and manager/service providers in relation to two bus stations. These exploratory findings raise some thought-provoking matters. In summary, the service providers/managers perceived that both bus stations have been designed with consideration of one or more design principles for crime prevention. Nevertheless, they were of the opinion that CPTED concepts were well detailed at Ring road bus station than at Uselu bus station. This suggests that Ring road bus station should be perceived by users to be safer than Uselu. Surprisingly, this was not the case. The commuters perceived Uselu terminal to exhibit marginally higher levels of security potentials and felt it was slightly safer than Ring road. Another important finding is that the users also felt that the image of Uselu bus station was more positive than Ring road. 
So what could influence this variation? Although a complete answer to this question is beyond the scope of this article, we can speculate. First, these could be due to the relatively small sample size of the respondents. Second, biases from facilities managers as they are likely to want to overstate their services and facilities. Third, the fact that Ring road bus station (based on our environmental audit) is located within a wider disorganized environment and transition zone of the city; with generally poor environs. Another possibility is that security strategies might not have been implemented as effectively as it should have been. Nonetheless, these findings provided some insights into the concept of wider environment of CPTED principles, underlining that crime generators, crime attractors, crime detractors, crime facilitators, and crime precipitators around the Ring road bus station may affect perceptions of the personal safety and the effectiveness of security strategies at the bus station itself.

These findings suggest that transport safety and security surveys need to include some kind of measurement of landuses around transport bus station; particularly in Nigeria. This is because the design of public transit bus stations in the country is generally poor. Asides, most parks do not enjoy basic services particularly electricity supply in the evening and night. However, public buses run till late hours in the night. The resultant effect is a squalid environment which act as breeding ground for criminal activities both within and around such stations. This empirical study does not suggest that CPTED does not work or is not a worthwhile investment for transportation facilities. Rather, it suggests that CPTED could be applied better by considering the wider environment. Indeed, understanding the context and nature of the immediate environment may help explain the negative image of Ring road bus station and its attempts to respond in terms of the redesign of the bus station using CPTED principles. It may well be the case that the CPTED design efforts simply were not enough to overcome the highly disorganized image of the area.

The authors recognize that there is limitations to this research in that caution should be applied in drawing any conclusions from rather low sample size respondents and nonrandomized selection technique of respondents. Further studies or more randomized surveys would need to be conducted to corroborate these findings; particularly on nonenvironmental factors influencing variations between transport managers and users perceptions. More detailed research on activities surrounding sites at which design out crime has been implemented may shed more light on this subject matter as well. It is also suggested that some form of personal safety survey of bus terminal users could become a more systematic and regular component of passengers' satisfaction and service quality surveys. This could then be used to redirect and target safety and security planning at specific bus stations. This also might be used in planning for the number and location of security personnel and devices. Besides, it can be used to transform the image of bus stations as a clean and well-kept environment provides a sense of orderliness and control, which can foster perceptions of safety as well as deter criminals at transport terminals.

\section{REFERENCES}

1. Ackerman, V. W., and Murray, T. A. 2004. Assessing spatial patterns of crime in Lima, Ohio. Cities, $21(5), 423-437$.

2. Ajayi, A.P., and Ajayi, D.D. 2013. Areal differentiation in crime in public transit bus stations in lbadan. Journal of Transportation Security, 6(1), 1-12.

3. Ajayi, A.P., and Ajayi, D.D. 2014. Trend analysis of crime incidences and crime vulnerability differentials on urban transport facilities in Ibadan. Journal of Intelligent Transportation and Urban Planning, 2(2), 85-97.

4. Andresen, M. A. 2006. A spatial analysis of crime in Vancouver, British Columbia: A synthesis of social disorganization and routine activity theory. The Canadian Geographer, 50(4), 487-502.

5. Armitage, R. 2016. Crime prevention through environmental design. In Environmental Criminology and Crime Analysis, R.Wortley, and M. Townsley. Routledge.

6. Armitage, R., \& Joyce, C. 2017. Why my house? - Exploring the influence of residential housing design on burglar decision-making. In Re-building Crime Prevention through Environmental Design (CPTED), R. Armitage, and P. Ekblom. Taylor and Francis.

7. Atlas, R., Sorensen, S., and Hayes, J. G. 2008. Understanding CPTED and situational crime prevention. In $21 s t$ Century Security and CPTED: Designing for Critical Infrastructure Protection and Crime Prevention, Randall I. A., 5378. CRC Press.

8. Batley, R., M., Rogerson, J., Nellthorp, M., Wardman, A., Hirschfield, A., Newton, J., Shires, L., Monchuk, R., Armitage, K., Sharratt, D., Johnson, P., and Chintakayala, P. 2012. Evaluating measures to improve personal security and the value of their benefits. Project Report. Rail Safety and Standards Board. Available: <http://eprints.hud.ac.uk/14650/> Accessed June 9, 2015.

9. Block, R., and Block C. R. 2000. The Bronx and Chicago: street robbery in the environs of rapid transit stations. In Analyzing Crime Patterns: Frontiers of Practice, Goldsmith, V., McGuire, P. G., Mollenkopf, J H., and T. A. Ross, 137-152. Sage Publications.

10. Brantingham, P. J., and Brantingham, P. L. 1993. Nodes, path, and edges: considerations on the complexity of crime and the physical environment. Journal of Environmental Criminology, 13, 3-28.

11. Brantingham, P. J., and Brantingham, P. L. 2008. Crime pattern theory. In Environmental Criminology and Crime Analysis, R. Wortley and L. Mazerolle, 78-93. Willan.

12. Breetzke, G. D., and Cohn, E. G. 2012. Seasonal assault and neighborhood deprivation in South Africa: Some preliminary findings. Environment and Behavior, 44, 641-667.

13. Cahill, M. E., and Mulligan, G. F. 2007. The determinants of crime in Tucson, Arizona. Urban Geography, 24, 582610.

14. Cao, L., and Maume, D. J. 1993. Urbanization, inequality, lifestyles and robbery: a comprehensive model. Sociological Focus, 26(1), 11-26.

15. Clarke, R., and J. Eck. 2005. Crime analysis for problem solvers_In 60 small steps. Center for Problem Oriented Policing, Washington DC. 
16. Cohen, L. E. and Felson, M. 1979. Social change and crime rate trends: A routine activity approach. American Sociological Review, 44(4), 588-608.

17. Cozens, P. 2014. Think Crime! Using Evidence, Theory and Crime Prevention through Environmental Design (CPTED) for Planning Safer Cities. Praxis Education.

18. Cozens, P. M. 2002. Exploring crime and the fear of crime within the railway environment. Public Transport International, 51, 20-24.

19. Cozens, P. M. 2008. Crime prevention through environmental design. In Environmental Criminology and Crime Analysis, R. Wortley, and L. Mazerolle. Willan Publishing.

20. Cozens, P. M., Neale, R. H., Whitaker, J., and Hillier, D. 2003a. Investigating personal safety at railway stations using 'virtual reality' technology. Facilities, 21(7/8), 188-193.

21. Cozens, P. M., Neale, R. H., Whitaker, J., and Hillier, D. 2003b. Managing crime and the fear of crime at railway stations-A case study in South Wales (UK). International Journal of Transport Management, 1(3), 121-132.

22. Cozens, P. M., Neale, R. H., Whitaker, J., and Hillier, D. 2004. Tackling crime and fear of crime while waiting at Britain's railway stations. Journal of Public Transportation, 7(3), 23-41.

23. Cozens, P., and Love, T. 2015. A review and current status of crime prevention through environmental design. Journal of Planning Literature, 30(4), 1-20.

24. Cozens, P., Saville, G., and Hillier, D. 2005. Crime prevention through environmental design (CPTED): A review and modern bibliography. Property Management, 23(5), 328-356.

25. Crime Concern. 2004. People perceptions of personal security and their concerns about crime on public transport: Research findings. Department for Transport, United Kingdom.

26. Delbosc, A., and Currie, G. 2012. Modelling the causes and impacts of personal safety perceptions on public transport ridership. Transport Policy, 24, 302-309.

27. Dragu, V., Roman, E., and Roman, V. 2013. Quality assessment in urban public transport. Theoretical and Empirical Research in Urban Management, 8(3), 32-43.

28. Ekblom, P. 2011. Deconstructing CPTED... and reconstructing it for practice, knowledge management and research. European Journal on Criminal Policy and Research, 17, 7-28.

29. Felson, M., and Boba, R. 2010. Crime and everyday life (4th Ed.). Sage Publications.

30. Jacobs, J. 1961. The death and life of great American cities. Random House.

31. Kinney, J. B., Brantingham, P. L., Wuschke, K., Kirk, M. G., and Brantingham, P. J. 2008. Crime attractors, generators and detractors: Land use and urban crime opportunities. Built Environment, 34(1), 62-74.

32. Lockwood, D. 2007. Mapping crime in savannah: Social disadvantage, land use, and violent crimes reported to the police. Social Science Computer Review, 25(2), 194-209.

33. Loukaitou-Sideris, A., Liggett, R., and Iseki, H. 2001. Measuring the effects of built environment on bus stop crime. Environment and Planning B: Planning and Design, 28, 255-280.

34. Ministry of Transport. 2015. Transport patronage statistics in Edo State. Edo State Government, Nigeria.

35. Moore, S. 2010. Preventing anti-social behaviour on public transport: An alternative route? Crime Prevention and Community Safety, 12(3), 176-193.

36. Newman, O. 1972. Defensible Space: Crime Prevention through Urban Design. Macmillan.

37. Newman, O. 1973. Defensible Space: People and Design in the Violent City. Architectural Press.

38. Newton A. D. 2004. Crime on public transport: static and non-static crime events. Western Criminology Review, 5(3), $25-42$.

39. Newton, A. 2008. Study of bus route crime risk in urban areas: The changing environs of a bus journey. Built Environment, 34(1), 88-103.

40. Newton, A. (2014). Crime on public transport. In The Encyclopedia of Criminology and Criminal Justice, 709-720. Springer.

41. Page, O., Moeketsi, P., Schurink, W., Molefe, L. and Bruce, D. 2001. Crime and crime prevention on public transport Reducing crime on public transport in South Africa appropriateness of crime prevention strategies. In Proceedings of the $20^{\text {th }}$ South African Transport Conference, $16-20$ July 2001. Pretoria.

42. Page, O., Moeketsi, P., Schurink, W., Molefe, L., and Bruce, D. 2001a. Crime and crime prevention on public transport. UNISA Press.

43. Peeters $M$ and Beken T. 2017. The relation of CPTED characteristics to the risk of residential burglary in and outside the city center of Ghent. Applied Geography, 86, 283-291.

44. Schneider, R. H. and Kitchen, T. 2002. Planning for crime prevention: A transatlantic perspective. Routledge.

45. Schneider, R. H. and Kitchen, T. 2007. Crime prevention and the built environment. Routledge.

46. Shaw, C.R. and Mckay, H.D. 1942. Juvenile delinquency and urban areas: A study of rates of delinquencies in relation to differential characteristics of local communities in American cities. University of Chicago Press.

47. Smith, M. J. 2008. Addressing the security needs of women passengers on public transport. Security Journal, 21, 117-133.

48. Smith, M. J., and Clarke, R. V. 2000. Crime and public transport. Crime and Justice, 27, 169-233.

49. Thompson, K., Offler, N., Hirsch, L., Every, D., Thomas, M. J., and Dawson, D. 2012. From broken windows to a renovated research agenda: $A$ review of the literature on vandalism and graffiti in the rail industry. Transportation Research Part A, 46(8), 1280-1290.

50. Vilalta, C. J. 2011. Fear of crime in public transport: Research in Mexico City. Crime Prevention and Community Safety, 13(3), 171-186

51. Weisburd, D., Groff, E. R., and Yang, S.-M. (2012). The criminology of Place: Street segments and our understanding of the crime problem. Oxford University Press.

52. Wilson, J. and Kelling, G. 1982. Broken windows. Atlantic Monthly, 249(3), 29-38. 
53. World Bank 2015. Crime and urban violence in cities. Conflict, Crime and Violence Team of Social Development Department, Washington DC.

54. Wortley, R. 2008. Situational crime precipitators. In Environmental Criminology and Crime Analysis, R. Wortley, 4869. Willan.

55. Ziegler, E. H. 2007. American cities, urban planning, and place-based crime Prevention. The Urban Lawyer, 39(4), 859-875.

\section{(c)}

This work is licensed under a Creative Commons Attribution 4.0 International License.

DOI: $10.24297 /$ jssr.v11i2.6365 